\section{Detection and molecular char- acterisation of swine Hepatitis E virus in Brescia province, Italy}

\author{
Enrico Pavoni, llaria Barbieri, \\ Barbara Bertasi, Guerino Lombardi, \\ Paolo Cordioli, Marina Nadia Losio \\ Veterinary Public Health Institute of \\ Lombardy and Emilia-Romagna, Brescia, \\ Italy
}

\section{Abstract}

Hepatitis E virus (HEV) is an important public health concern in many developing countries and it occurs in sporadic forms in industrialized areas. With the discovery of swine HEV in pigs, which is genetically closely related to human $\mathrm{HEV}$, hepatitis $\mathrm{E}$ is considered to be a zoonotic disease. To investigate the circulation of HEV within a distinct area of Lombardy region (Northern Italy), 17 pig farms were subjected to monitoring study by collection of fresh stool samples each represented by ground-pooled specimens. In particular, three distinct types of breeding farms were focused, represented by farrow to weaning, farrow to finish and fattening farms, respectively. Epidemiological data confirm that in Europe the seroprevalence in pigs, more than 9 month of age, ranges from 51.4 to $75 \%$, while in $3-9$ months fatteners is about 38\%. In France and Italy, the positivity among farms is respectively 30 and $97.4 \%$ and the seroprevalence in Italy is $50.2 \%$. Since HEV viremia was typically observed in the early period of life in swine, faeces were collected in boxes containing weaning pigs. For the study, 183 stool samples were collected and amplifications were performed with universal primers specific for the 0RF2 region of genome. Twentyeight samples resulted positive to HEV RNA and genotyping demonstrated that they were closely related to HEV strains belonging to genotype 3 and circulating in Europe. Comparison with reference strains from GenBank excluded their similarity to genotype 1, 2 or 4 confirming that genotype 3 strains are circulating in Europe. Since it was demonstrated that swine act as a reservoir for $\mathrm{HEV}$, and since many strains into HEV genotype 3 share a strong molecular similarity to human HEV, it was important to detect the presence of $\mathrm{HEV}$ in a restricted area with a very high density of pigs.

\section{Introduction}

Hepatitis E virus (HEV) is a not enveloped, single stranded, positive-sense RNA virus. The genomic RNA is about $7.5 \mathrm{~kb}$ and contains three open reading frames (ORFs): ORF1 is predicted to encode non-structural proteins, ORF2 encodes the putative capsid protein, and ORF3 encodes a cytosckeleton-associated phosphoprotein (Meng et al., 2002). HEV has recently been classified as the prototype member in the Hepevirus genus, Hepeviridae family. Although HEV strains belong to a single serotype, they show a considerable genetic diversity, according to time and place of isolation (Aggarwal and Naik, 2009); there exist at least four major genotypes (G1 to G4): type 1 (Asian strains, also detected in Europe associated with travellers, type 2 (Mexican and African strains), type 3 (strains from sporadic human cases in industrialized countries, also found in swine, wild boar, and sika deer). Type 4 strains, from human sporadic cases in East Asia, were also detected in Italy in humans (Garbuglia et al., 2013) and in pigs (Monne et al., 2015).

HEV is transmitted primarily by the faecaloral route through contaminated water, and is the causative agent of hepatitis $\mathrm{E}$, a self-limited enterically transmitted, non-A, non-B hepatitis in humans. Sporadic cases of hepatitis $\mathrm{E}$ have been documented in the United States and Europe mostly referred to travellers or pig handlers and veterinarians (Van Cuyck et al., 2005). Hepatitis E is a zoonotic disease as HEV was found in pigs (Martinelli et al., 2011; Gardinali et al., 2012), wild boar (Takahashi et al., 2004; Martinelli et al., 2015; Caruso et al., 2015), and since HEV infection was described among people who had eaten uncooked-infected deer meat (Tei et al., 2003) and raw pork liver sausages (Renou et al., 2014). Further observations confirming the association between pig liver or uncooked meat consumption, wild boar, or deer, and hepatitis $\mathrm{E}$ were reported also in Europe (Ruggeri et al., 2013b). The transmission to humans through food by the ingestion of infected meat products is not much probable when the virus is inactivated by the process of cooking, even if it has been described that swine HEV could have been transmitted to human beings after the consumption of fried and grilled pig liver (Yazaki et al., 2003).

The human and swine HEV isolates from industrialized countries are genetically clustered together in the same genotype (either G3 or G4) (Pavio et al., 2010; Ruggeri et al., 2013b). Veterinarians, slaughterhouse workers and pig handlers, show an increased prevalence of anti-HEV antibodies, suggesting a potential pig-to-human HEV transmission (Di Bartolo et al., 2011; Carpentier et al., 2012). In Italy, in the last two decades, 5 sequences on 22 autochthonous (not related to travels abroad) HEV sporadic cases were genotyped and all these strains were G3 HEV (Zanetti et
Correspondence: Enrico Pavoni, Veterinary Public Health Institute of Lombardy and EmiliaRomagna, Brescia, Italy, via Bianchi 9, 25124, Brescia, Italy.

Tel: +39.030 .2290611 - Fax: +39.030 .2290542 .

E-mail: enrico.pavoni@izsler.it

Key words: Hepatitis E virus; RT-PCR; Swine; Zoonosis.

Acknowledgements: the authors thank Dario De Medici (National Institute of Health, Rome, Italy) for his contribution.

Received for publication: 17 July 2014

Revision received: 19 December 2014.

Accepted for publication: 20 December 2014

This work is licensed under a Creative Commons Attribution 3.0 License (by-nc 3.0).

(C) Copyright E. Pavoni et al., 2015

Licensee PAGEPress, Italy

Italian Journal of Food Safety 2015; 4:4587

doi:10.4081/ijfs.2015.4587

\section{al., 1999; Romanò et al., 2011).}

In swine, the natural route(s) for HEV transmission remain unknown, even if repeated direct daily contact among pigs confined in the same pen may enhance the spread of the virus. Moreover, it was shown that swine HEV viremia and faecal virus shedding generally occur in pigs of 2 to 4 months of age (Cooper et al., 2005; Vasickova et al., 2009). However, the prevalence of HEV in pig faeces may be more various (Di Bartolo et al., 2011; Martinelli et al., 2011).

Nevertheless, people such as breeders, slaughterers and veterinarians could be at risk of infection, as already demonstrated (Meng et al., 2002; Ruggeri et al., 2013a). Recent virological surveys in Europe detected HEV in high sample proportions (often $>40 \%$ ) from apparently healthy animals at slaughterhouses, next to entering the pork production chain and being commercialized (Ruggeri et al., 2013b).

In Germany $42.7 \%$ to $50.3 \%$ pig sera were found to be anti-HEV IgG-positive. While $38.4 \%$ of fatteners (age between 3 and 9 months) exhibited HEV-specific antibodies, $51.4 \%$ of sows age older than 9 months exhibited antiHEV antibodies. Fatteners kept in Southern Germany had a significantly higher HEV IgG prevalence compared to fatteners in the Northern federal states (Krumbholz et al., 2013; Dremsek et al., 2013). In France, 30\% of the sampled farms resulted positive for HEV detection, while seroprevalence in slaughterage pigs at the farm level reached almost $75 \%$ (Walachowski et al., 2014). In Italy, 97.43\% of farms and $50.21 \%$ of swine sera resulted positive for anti-HEV IgG antibodies, confiming that $\mathrm{HEV}$ is widespread in pigs in Italy and 
might be endemic on most farms (Martinelli et al., 2011).

Since the Province of Brescia (Lombardy Region, Northern Italy) has an intense breeding activity of pigs, and since there are scarce informations about HEV in local farms, the aim of this study was to collect preliminary data referring to the prevalence of HEV among different types of breeding farms.

\section{Materials and Methods}

\section{Sample collection}

Since this survey was intended to obtain preliminary data about the possible circulation of HEV among local pig farms, the herd types were selected based on the willingness of farmers. Also, no specific sampling criteria were selected for the collection of faecal specimens. The considered geographic area was limited to about $240 \mathrm{~km}^{2}$ in the southern side of the province of Brescia, (Northern Italy). Since in the province of Brescia there are more than 1,400,000 heads, with 224 farrow to weaning, 105 farrow to finish, 379 fattening farms, and that there are $>0.17$ farms $/ \mathrm{km}^{2}$, this southern district was an area of high pig density (more than 1400 animals $/ \mathrm{km}^{2}$ ) (Zanardi et al., 2007; Bellini et al., 2007). One hundred eighty three faecal samples were collected from pigs 2-4 month-old, housed in 17 herds ( 7 farrow to weaning, 5 farrow to finish and 5 fattening farms, respectively). The number of animals ranged from 400 to 4500 per herd. The average number of sows in farms with $>1000$ animals was 250 . Acquired pigs in fattening farms were $20-45 \mathrm{~kg}$ (live weight) and 3 months old. Each sample weighted $100 \mathrm{~g}$, and was the result of a random collection of fresh stool harvested in five different points from the ground of pens containing 20-25 young animals each. The number of faecal samples by herd is reported in Table 1, and the average value of collections is 10 per farm.

\section{Viral RNA extraction}

Stools were clarified with sterile RNase-free water 1:10 w/v and viral RNA was extracted using a commercial kit with silica membranes (Nucleospin RNA II kit; Macherey, Nagel, Germany). Briefly, $100 \mu \mathrm{L}$ of faecal suspension were added to $350 \mu \mathrm{L}$ of a guanidinium isothiocyanate-buffer and $3.5 \mu \mathrm{L}$ of $\beta$-mercaptoethanol for the lysis of cells. Then, $350 \mu \mathrm{L}$ of $70 \%$ ethanol were added, and the suspension was centrifuged 1 minute at $11,000 \mathrm{x}$ g. Contaminating DNAwas removed by a DNase I solution directly applied onto the silica membranes (95 $\mu \mathrm{L}$ of a 10\% DNase solution) for 15 minutes at room temperature. Three washing steps with two different buffers removed salts, metabolites and PCR inhibitors. Pure RNA was finally eluted with $60 \mu \mathrm{L}$ of RNase-free-water, centrifugating at $11,000 \mathrm{x}$ g for $1 \mathrm{~min}$.

\section{Real-time nested polymerase chain reaction}

Viral RNA was reverse transcribed with random primers into cDNA, and a Nested PCR was performed, following a protocol previously described (Erker et al., 1999). Since the viral genome was extracted from stool, cDNA was amplified both undiluted and 1:10 diluted, to avoid inhibitions to the PCR.

Degenerate primers detected all HEV strains targeting the ORF2 region of genome, also with significant sequence variations.

For the reaction, $1.5 \mathrm{mM} \mathrm{MgCl}_{2}, 0.1 \mathrm{mM}$ each dNTPs, and $0.5 \mu \mathrm{M}$ each primers were employed. $\quad 0.02 \mathrm{U} / \mu \mathrm{L}$ AmpliTaq DNA Polymerase (Life Technologies -USA) was used. The primers for the first PCR were ORF2S1 (5'-GAC AGA ATT RAT TTC GTC GGC TGG3 ') and ORF2-A1 (5'-CTT GTT CRT GYT GGT TRT CAT AAT C-3'), while for the Nested PCR were 0RF2-S2 (5'-GTY GTC TCR GCC AAT GGC GAG C-3') and ORF2-A2 (5'-GTT CRT GYT GGT TRT CAT AAT CCT G-3'). PCRs were carried out in $0.2-\mathrm{mL}$ microcentrifuge tubes with $55 \mu \mathrm{L}$ of PCR-master-mix and $5 \mu \mathrm{L}$ of template cDNA and tubes were then placed in an automated thermal cycler (Gene Amp PCR System 9700; Life Technologies, Carlsbad, CA, USA). PCR and Nested PCR reactions, were processed with an initial inactivation step at $95^{\circ} \mathrm{C}$ for 3 min, followed by 35 cycles of denaturation at $95^{\circ} \mathrm{C}$ for $1 \mathrm{~min}$, annealing at $55^{\circ} \mathrm{C}$ for $30 \mathrm{sec}$, and elongation at $72^{\circ} \mathrm{C}$ for $1 \mathrm{~min}$. Final elongation step was $72^{\circ} \mathrm{C}$ for $10 \mathrm{~min}$; PCR products were separated by agarose gel electrophoresis (2.5\%) in $1 \mathrm{X}$ TAE buffer [ $(0.04 \mathrm{M}$ Tris-acetate, 0.001 M EDTA (pH 8.00)], stained with ethidium bromide. Images were visualized on UV light and reproduced by a digital camera with Kodak 1D 3.6 program (expected PCR product: 145 bp).

\section{Nucleotide sequencing and phylo- genetic analysis}

PCR products were purified with QIAquick ${ }^{\circledR}$ Gel Extraction Kit (Qiagen, Valencia, CA, USA) and then cycle sequenced on both strands of ORF2 PCR by BigDye ${ }^{\circledR}$ Terminator Cycle Sequencing kit (v1.1; Applied Biosystems, Carlsbad, CA, USA) using the same primers as used for nested PCR amplification. Sequence reactions were separated on ABI3130 genetic analyzer (Applied Biosystems). Sequences were assembled using SeqMan (Lasergene package; DNAStar Inc., Madison, WI, USA) and

Table 1. Distribution of Hepatitis E virus strains per different herd types.

\begin{tabular}{|c|c|c|c|c|c|}
\hline Herd (n.) & $\begin{array}{l}\text { Herd } \\
\text { (type) }\end{array}$ & $\begin{array}{l}\text { Breeded } \\
\text { animals } \\
\text { (n.) }\end{array}$ & $\begin{array}{c}\text { Samples } \\
\text { collected } \\
\text { (n.) }\end{array}$ & $\begin{array}{c}\text { Positive } \\
\text { samples } \\
\text { (n.) }\end{array}$ & $\begin{array}{c}\text { Strains } \\
\text { (n.) }\end{array}$ \\
\hline 1 & FW & 2000 & 10 & - & \\
\hline 2 & FW & 1000 & 22 & - & \\
\hline 3 & FW & 2700 & 13 & - & \\
\hline 4 & FW & 1200 & 11 & 2 & $\begin{array}{c}\text { N1 (1), } \\
\text { HUN-E113NH1 (1) }\end{array}$ \\
\hline 5 & FW & 2000 & 10 & - & \\
\hline 6 & FW & 1800 & 10 & 2 & BCN-5 (2) \\
\hline 7 & FW & 3600 & 10 & - & \\
\hline Total FW & 7 & 14,300 & 86 & 4 & \\
\hline 8 & $\mathrm{FF}$ & 1150 & 13 & 4 & NLSw28/BCN-12 (4) \\
\hline 9 & $\mathrm{FF}$ & 800 & 6 & - & \\
\hline 10 & $\mathrm{FF}$ & 1200 & 10 & 1 & NLSw28/BCN-12 (1) \\
\hline 11 & $\mathrm{FF}$ & 3000 & 10 & - & \\
\hline 12 & $\mathrm{FF}$ & 400 & 10 & 6 & W1 (6) \\
\hline Total FF & 5 & 16,900 & 49 & 11 & \\
\hline 13 & $\mathrm{FA}$ & 500 & 10 & 2 & BCN10 (2) \\
\hline 14 & $\mathrm{FA}$ & 3300 & 10 & 4 & HUN-E113/NH1 (4) \\
\hline 15 & $\mathrm{FA}$ & 1038 & 10 & - & \\
\hline 16 & $\mathrm{FA}$ & 2800 & 8 & 5 & NLSw28/BCN12 (4), W1 (1) \\
\hline 17 & $\mathrm{FA}$ & 4500 & 10 & 2 & W1 (2) \\
\hline Total FA & 5 & 12,138 & 48 & 13 & \\
\hline Total & 17 & 43,338 & 183 & 28 & \\
\hline
\end{tabular}

FW, farrow to weaning; FF, farrow to finish; FA, fattening. In the last column, the reference strains (and their number) with higher similarity

to the sequence obtained in positive samples. 
aligned by using the Clustal W programme. Sequences were subjected to BLAST search at http://www.ncbi.nlm.nih.gov/pubmed. Phylogenetic analysis was performed using as references HEV sequences belonging to genotype 1 to 4 according to the currently most accepted HEV classification proposed by Lu $e t$ al. (2006). Unrooted tree was generated using the distance-based Neighbor-Joining method determined on the base of the model selection function implemented within the MEGA 5 software. Bootstrap values were calculated on 1000 replicates of the alignment.

\section{Results}

Among the 183 stool samples tested, each represented by ground-pooled specimens, 28 (15.3 \%) were positive for the HEV RNA. Positive samples were found in 4 of the 5 fattening (FA) farms, in 3 of the 5 farrows to finish (FF) herds, and in 2 of the 7 farrows to weaning (FW) herds (Table 1). Blast search of partial ORF 2 sequences obtained, revealed that HEV strains of the present study could be clustered in at least 67 groups based on the \% percentage of nucleotide identity towards HEV strains retrieved from GenBank (Table 2). In particular, group 1 (5 sequences) was $94 \%$ identical to swine HEV strain NLSw28 (AF336292) and 91-92\% similar to BCN12 strain (AF490993). Group 2 (4 sequences) showed $97 \%$ identity to BCN12 strain (AF490993) and 95\% to NLSw28 (AF336292). Group 3 (9 sequences) shared $92 \%$ similarity with W1 strain (AF490998); Group 4 (2 sequences) shared $98 \%$ similarity with BCN5 strain (AF490986) and 94-95\% with NLSw28 (AF336292); group 5 (2 sequences) shared 94\% similarity with N1 strain (AF490999) and 92\% to HUN-E113 (EF530669); group 6 (2 sequences) was $94 \%$ similar to BCN10 strain (AF490991); group 7 (4 sequences) showed 94\% nucleotide identity with strain HUN-E113 (EF530669) and 91\% similarity with VH1 strain (AF401000).

Sequences similar to BCN-12, NLSw28 and W1 strain derived from viruses circulating among farrow to finish pig farms, while those related to N1, VH1, HUN-E113 and BCN-5 strain were from HEV detected in farrow to weaning pig farms. HEV sequences similar to BCN10, BCN12, W1, NLSw28, HUN-E113 and VH1 strain were recovered in fattening farms (Table 1). Phylogenetic analysis (Figure 1) conducted comparing the sequences of the present work to HEV reference sequences (according to the classification proposed by Lu et al., 2006), revealed that all the sequences could be placed in different branches within Genotype 3. It also confirmed the presence of 7 main clusters within genotype 3 and excluded any relation to genotype 1,2 and 4 . In particular, sequences belonging to group 1,2 and 4 grouped together with reference sequence of genotype $3 \mathrm{f}$. Sequences of group 5 were more related to genotype 3c sequences; group 6 sequences clustered among genotype $3 \mathrm{~h}$. As for sequences of groups 3 and 7 further subtyping was not possible. This was probably due to

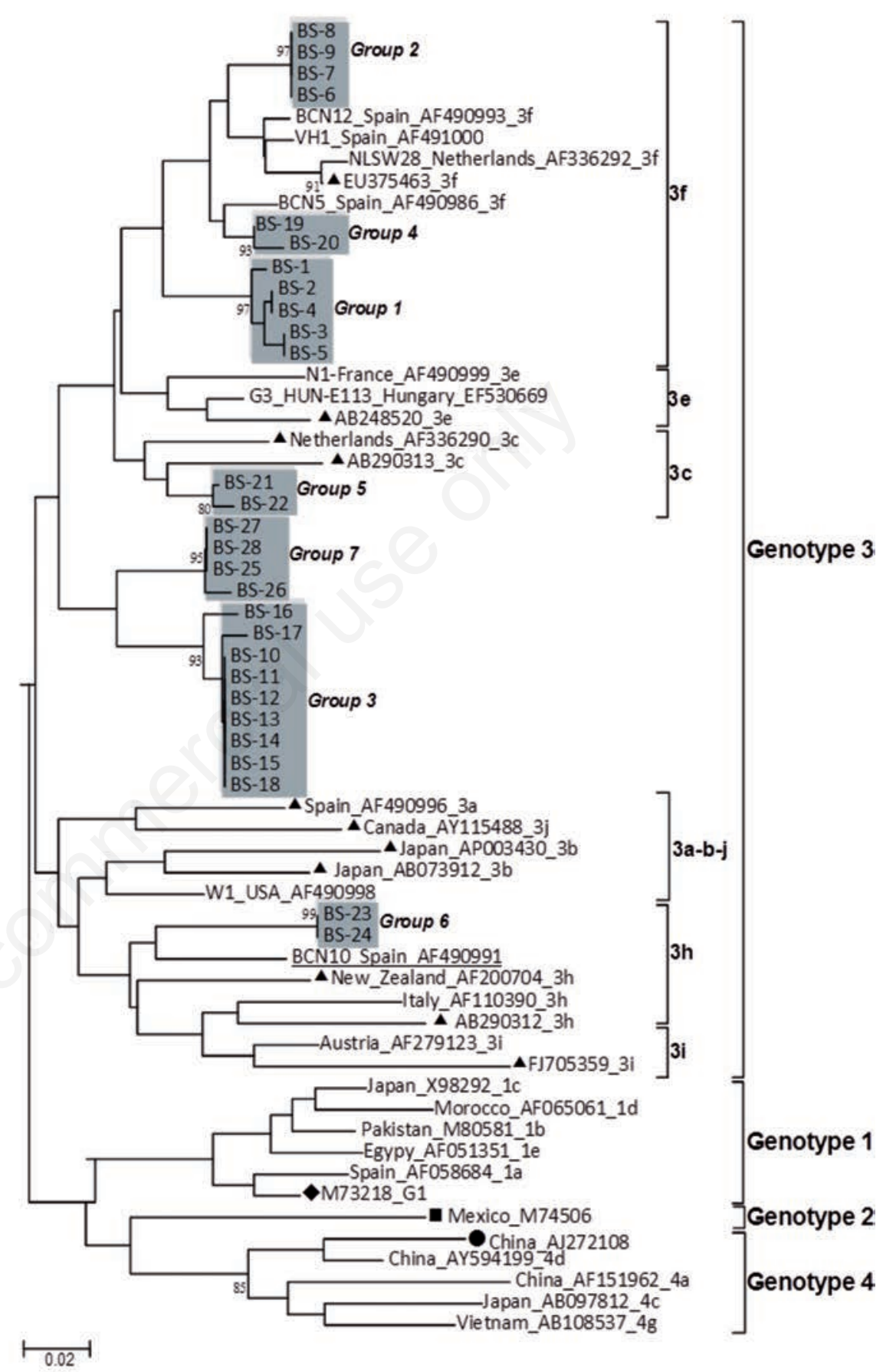

Figure 1. Phylogenetic relationship over a 122-bp fragment within ORF2 among 28 Hepatitis $\mathrm{E}$ virus strains of this study and reference sequences belonging to $\mathrm{HEV}$ genotype and subtype, according to Lu et al. (2006) classification. Genotype I ( $\diamond)$; genotype II $(\bullet)$; genotype IV $(\bullet)$. Within genotype III, reference sequences referred to each known subtype are marked as $\boldsymbol{\Delta}$. Hepatitis $E$ virus sequences belonging to groups 1 to 7 are highlighted in grey boxes. Sequence AF110390 represents a human sporadic case in Italy (Zanetti et al., 1999). Unrooted tree was constructed using the Neighbor-Joining method (MEGA 5). Bootstrap values represent the percentage of 1000 trees supporting the clustering; only values above $70 \%$ are shown. 
the existence of possible inconsistencies within current HEV classification especially when applied to the analysis of partial ORF2 region (Oliveira-Filho et. al., 2013). No simultaneous infection of different strains was detected in positive samples.

\section{Discussion}

The aim of this study was to estimate the prevalence of HEV-positive farms in a limited area in the southern side of the province of Brescia (Lombardy Region, Northern Italy). Monitoring data showed 28 positive samples (15.3\%) confirmed as swine HEV strains by sequencing the PCR products, corresponding to a partial region of the ORF2. All positive samples were characterized as belonging to the HEV G3, due to their high similarity to G3 strains previously detected in Spain, Netherlands and Hungary (Clemente-Casares et al., 2003; van der Poel et al., 2001; Reuter et al., 2009). Sequences similar to N1, HUNE113, VH1, and BCN-5 strains derived from viruses present in FW pig farms, while those related to NLSw28, BCN-12 and $\mathrm{W} 1$ derived from viruses circulating among $\mathrm{sFF}$ pig farms. HEV sequences similar to $\mathrm{BCN10}$, and the other previously cited strains (except for BCN5), were collected in FA herds (Table 1). Higher diversity in positive samples was detected in $2 / 7$ (28.6\%) FW farms, while the prevalence of positive $\mathrm{FF}$ farms was $3 / 5$ (60\%). Four FA farms out of $5(80 \%)$ resulted positive for HEV-PCR detection. All categories of farms resulted positive for $\mathrm{HEV}$, but preliminary data did not permit to assign a statistically significant difference between them. However, FA system seemed to be linked to a higher diversity of HEV strain types and to a higher percentage of positive farms; this could be due to the diverse origins of the 3-3.5 months old introduced piglets (domestic and foreign), contributing to enhance the difference of strains and the HEV infection rate.

The total $15.3 \%$ value of positive samples (28/183), indicates that HEV was actually circulating among the swine population in the province of Brescia, and that results were not sporadic. This percentage is lower than that previously reported for individual faecal swabs in 3-4 months old weaners (Di Bartolo et al., 2008), and for faeces at slaughterhouse in Italy (Di Bartolo et al., 2011, 2012) (33\% and 41\% respectively), but are closely related to the European average (27\%). However, data reported in our study is referred to a small geographic area, even if with a very high density of pigs' population.

Hepatitis E infection in humans is typically associated with endemic areas (Asia, Africa and South America), but HEV has also been isolated in patients with acute infections in countries where HEV is not endemic (Lin et al., 2014). G3 and G4 circulate among humans in Europe and G3 is widespread in pigs, including Italy and other European countries (Di

Table 2. Sequences of the 28 positive field samples of the present work subjected to Blast search.

\begin{tabular}{|c|c|c|c|c|c|c|}
\hline Sample & Strain ID & Accession number & $\%$ Identity & Origin of HEV & Source of HEV & Group/genotype \\
\hline BS-1 & BCN12/NLSw28 & AF490993/AF336292 & $94 / 92$ & Spain/Netherlands & Sewage/swine & $1 / 3 \mathrm{f}$ \\
\hline BS-2 & BCN12/NLSw28 & AF490993/AF336292 & $94 / 92$ & Spain/Netherlands & Sewage/swine & $1 / 3 \mathrm{f}$ \\
\hline BS-3 & BCN12/NLSw28 & AF490993/AF336292 & $94 / 91$ & Spain/Netherlands & Sewage/swine & $1 / 3 \mathrm{f}$ \\
\hline BS-4 & BCN12/NLSw28 & AF490993/AF336292 & $94 / 92$ & Spain/Netherlands & Sewage/swine & $1 / 3 \mathrm{f}$ \\
\hline BS-5 & BCN12/NLSw28 & AF490993/AF336292 & $94 / 91$ & Spain/Netherlands & Sewage/swine & $1 / 3 \mathrm{f}$ \\
\hline BS-6 & BCN12/NLSw28 & AF490993/AF336292 & $97 / 95$ & Spain/Netherlands & Sewage/swine & $2 / 3 \mathrm{f}$ \\
\hline BS-7 & BCN12/NLSw28 & AF490993/AF336292 & $97 / 95$ & Spain/Netherlands & Sewage/swine & $2 / 3 \mathrm{f}$ \\
\hline BS-8 & BCN12/NLSw28 & AF490993/AF336292 & $97 / 95$ & Spain/Netherlands & Sewage/swine & $2 / 3 \mathrm{f}$ \\
\hline BS-9 & BCN12/NLSw28 & AF490993/AF336292 & $97 / 95$ & Spain/Netherlands & Sewage/swine & $2 / 3 \mathrm{f}$ \\
\hline BS-10 & W1 & AF490998 & 92 & USA & Sewage & $3 / 3$ \\
\hline BS-11 & W1 & AF490998 & 92 & USA & Sewage & $3 / 3$ \\
\hline BS-12 & W1 & AF490998 & 92 & USA & Sewage & $3 / 3$ \\
\hline BS-13 & W1 & AF490998 & 92 & USA & Sewage & $3 / 3$ \\
\hline BS-14 & W1 & AF490998 & 92 & USA & Sewage & $3 / 3$ \\
\hline BS-15 & W1 & AF490998 & 92 & USA & Sewage & $3 / 3$ \\
\hline BS-16 & W1 & AF490998 & 92 & USA & Sewage & $3 / 3$ \\
\hline BS-17 & W1 & AF490998 & 92 & USA & Sewage & $3 / 3$ \\
\hline BS-18 & W1 & AF490998 & 92 & USA & Sewage & $3 / 3$ \\
\hline BS-19 & BCN5/NLSw28 & AF490986/AF336292 & $98 / 95$ & Spain/Netherlands & Sewage/swine & $4 / 3 \mathrm{f}$ \\
\hline BS-20 & BCN5/NLSw28 & AF490986/AF336292 & $98 / 94$ & Spain/Netherlands & Sewage/swine & $4 / 3 \mathrm{f}$ \\
\hline BS-21 & N1/HUN-E113 & AF490999/EF530669 & $94 / 92$ & France/Hungary & Sewage/human & $5 / 3 c$ \\
\hline BS-22 & N1/HUN-E113 & AF490999/EF530669 & $94 / 92$ & France/Hungary & Sewage/human & $5 / 3 c$ \\
\hline BS-23 & BCN10 & AF490991 & 92 & Spain & Sewage & $6 / 3 \mathrm{~h}$ \\
\hline BS-24 & BCN10 & AF490991 & 92 & Spain & Sewage & $6 / 3 \mathrm{~h}$ \\
\hline BS-25 & HUN-E113/NH1 & EF530669/AF491000 & $94 / 91$ & Hungary/Spain & Human & $7 / 3$ \\
\hline BS-26 & HUN-E113NH1 & EF530669/AF491000 & $94 / 91$ & Hungary/Spain & Human & $7 / 3$ \\
\hline BS-27 & HUN-E113/NH1 & EF530669/AF491000 & $94 / 91$ & Hungary/Spain & Human & $7 / 3$ \\
\hline BS-28 & HUN-E113NH1 & EF530669/AF491000 & $94 / 91$ & Hungary/Spain & Human & $7 / 3$ \\
\hline
\end{tabular}

HEV, Hepatitis E virus; Based on blast scores, sequences could be distinct into 7 groups (1 to 7) showed in the column Group/genotype together with the assigned HEV genotype and subtype when possible. 
Bartolo et al., 2008; Berto et al., 2012a, 2012b). The increasing cases of sporadic human HEV infections in countries of non-endemicity and the considerable rate of anti-HEV prevalence in sera (30-40\%) (Candido et al., 2012; Rapicetta et al., 2013) indicates that humans are at risk of infection more than estimated. Moreover, human RNA sequences appear to be closely related to the swine RNA detected in the same countries (Purdy and Khudyakov, 2010).

As being HEV infection asymptomatic in pigs, particular attention could be paid to the production and the processing of pork meat, because the virus is potentially pathogen for human consumers. This is particularly important in those Italian regions where alimentary traditions are strictly linked to the consumption of raw pork meat. The HEV survival in some typical Italian swine-products, such as salami and sausages needs to be evaluated either during seasoning; in fact, recent studies confirmed that HEV present in pork liver sausage was still infectious, highlighting the actual risk for consumers (Berto et al., 2012a, 2012b, 2013; Renou et al., 2014).

\section{Conclusions}

In spite of the few considered breeding plants (17) and the low number of analysed samples (183), this work evidenced the circulation of HEV in Italian pig population, even in a restricted area. The data obtained could be considered indicative as the starting point for a deeper study about a hypothetical correlation between the HEV spreading in swine population and sporadic cases of hepatitis $\mathrm{E}$ in humans. This fact was already discussed in a recent report from European Food Safety Authority biohazard experts (EFSA, 2011) who underscored an urgent need for integrated studies on HEV circulation, performing farm to table integrated risk assessment. The correct understanding of the impact of the breeding system (farrow to weaning, farrow to finish, and fattening) on HEV epidemiology, as described above, needs further study.

\section{References}

Aggarwal R, Naik S, 2009. Epidemiology of hepatitis E: current status. J Gastroen Hepatol 24:1484-93.

Bellini S, Avisani D, Alborali L, Bonazza V, Brocchi E, G. Zanardi G, 2007. Malattia vescicolare del suino in Lombardia 20062007. Available from: http://www. izsler.it/izs_bs/ftp//doc/Archivio/2007/2007
Ottobre.pdf

Berto A, Baker Jantien A, Mesquita JR, Nascimento MSJ, Banks M, Martelli F, Ostanello F, Angeloni G, Ruggeri FM, Di Bartolo I, Vasickova P, Diez-Valcarce M, Hernandez M, Rodriguez-Lazaro D, van der Poel WHM, 2012. Prevalence and transmission of hepatitis $\mathrm{E}$ virus in domestic swine populations in different European countries. BMC Res Notes 5:190.

Berto A, Martelli F, Grierson S, Banks M, 2012. Hepatitis E virus in pork food chain: United Kingdom, 2009-2010. Emerg Infect Dis 18:1358-60.

Berto A, Grierson S, Hakze-van der Honing R, Martelli F, Johne R, Reetz J, Ulrich RG, Pavio N, Van der Poel WHM, Banks M, 2013. Hepatitis $\mathrm{E}$ virus in pork liver sausage, France. Emerg Infect Dis 19:2.

Carpentier A, Chaussade H, Rigaud E, Rodriguez J, Berthault C, Boue F, Tognon M, Touze A, Garcia-Bonnet N, Choutet P, Coursaget P, 2012. High hepatitis E virus seroprevalence in forestry workers and in wild boars in France. J Clin Microbiol 50:2888-93.

Candido A, Taffon S, Chionne P, Pisani G, Madonna E, Dettori S, Valdarchi C, Bruni $\mathrm{R}$, Ciccaglione AR, 2012. Diagnosis of HEV infection by serological and realtime PCR assays: a study on acute non-A-C hepatitis collected from 2004 to 2010 in Italy. BMC Res Notes 5:297.

Caruso C, Modesto P, Bertolini S, Peletto S, Acutis PL, Dondo A, Robetto S, Mignone W, Orusa R, Ru G, Masoero L, 2015. Serological and virological survey of hepatitis $\mathrm{E}$ virus in wild boar populations in northwestern Italy: detection of HEV subtypes 3e and 3f. Arch Virol 160:153-60.

Clemente-Casares P, Pina S, Buti M, Jardi R, Martín M, Bofill-Mas S, Girones R, 2003. Hepatitis E virus epidemiology in industrialized countries. Emerg Infect Dis 9:4.

Cooper K, Huang FF, Batista L, Rayo CD, Bezanilla JC, Toth TE, Meng XJ, 2005. Identification of Genotype 3 Hepatitis E virus (HEV) in serum and faecal samples from pigs in Thailand and Mexico, where Genotype 1 and 2 HEV strains are prevalent in the respective human populations. $\mathrm{J}$ Clin Microbiol 43:1684-8.

Di Bartolo I, Martelli F, Inglese N, Pourshaban M, Caprioli A, Ostanello F, Ruggeri FM, 2008. Widespread diffusion of genotype 3 hepatitis E virus among farming swine in Northern Italy. Vet Microbiol 132:47-55.

Di Bartolo I, Ponterio E, Castellini L, Ostanello F, Ruggeri FM. Viral and antibody HEV prevalence in swine at slaughterhouse in Italy, 2011. Vet Microbiol 149:330-8.

Di Bartolo I, Diez-Valcarce M, Vasickova P, Kralik P, Hernandez M, Angeloni G, Ostanello F, Bouwknegt M, Rodríguez-
Lázaro D, Pavlik I, Ruggeri FM, 2012. Hepatitis E virus in pork production chain in Czech Republic, Italy, and Spain, 2010. Emerg Infect Dis 18:8.

Dremsek P, Joel S, Baechlein C, Pavio N, Schielke A, Ziller M, Dürrwald R, Renner C, Groschup MH, Johne R, Krumbholz A, Ulrich RG, 2013. Hepatitis E virus seroprevalence of domestic pigs in Germany determined by a novel in-house and two reference ELISAs. J Virol Methods 190:116.

Erker JC, Desai SM, Mushahawar IK, 1999. Rapid detection of Hepatitis E virus RNA by reverse transcription-polymerase chain reaction using universal oligonucleotide primers. J Virol Methods 81:1-2.

EFSA, 2011. European Food Safety Authority Panel on biological hazard. Scientific opinion on an update on the present knowledge on the occurrence and control of foodborne viruses. EFSA J 9:1-96.

Garbuglia AR, Scognamiglio P, Petrosillo N, Mastroianni C M, Sordillo P, Gentile D, La Scala P, Girardi E, Capobianchi MR, 2013. Hepatitis E virus genotype 4 outbreak, Italy, 2011. Emerg Infect Dis 19:110-4.

Gardinali NR, Barry AF, da Silva PFN, de Souza C, Alfieri AF, Alfieri AA, 2012. Molecular detection and characterization of hepatitis $\mathrm{E}$ virus in naturally infected pigs from Brazilian herds. Res Vet Sci 93:1515-9.

Krumbholz A, Joel S, Neubert A, Dremsek P, Durrwald R, Johne R, Hlinak A, Walther M, Lange J, Wutzler P, Sauerbrei A, Ulrich RG, Zell R, 2013. Age-related and regional differences in the prevalence of hepatitis $\mathrm{E}$ virus-specific antibodies in pigs in Germany. Vet Microbiol 167:394-402.

Lin J, Norder H, Uhlhorn H, Belák S, Widén F, 2014. Novel hepatitis E like virus found in Swedish moose. J Gen Virol 95:557-70.

Lu L, Li C, Hagedorn CH, 2006. Phylogenetic analysis of global hepatitis E virus sequences: genetic diversity, subtypes and zoonosis. Rev Med Virol 16: 5-36.

Martinelli N, Luppi A, Cordioli P, Lombardi G, Lavazza A, 2011. Prevalence of hepatitis E virus antibodies in pigs in Northern Italy. Infect Ecol Epidemiol 1:7331.

Martinelli N, Pavoni E, Filogari D, Ferrari N, Chiari M, Canelli E, Lombardi G, 2015. Hepatitis E virus in wild boar in the central Northern part of Italy. Transbound Emerg Dis 62:217-22.

Meng X-J, Wiseman B, Elvinger F, Guenette DK, Toth TE, Engle RE, Emerson SU, Purcell RH, 2002. Prevalence of antibodies to hepatitis $\mathrm{E}$ virus in veterinarians working with swine and in normal blood donors in the United States and other Countries. $\mathrm{J}$ Clin Microbiol 117-22.

Monne S, Ceglie L, DI Martino G, Natale A, Zamprogna S, Morreale A, Rampazzo E, 
Cattoli G, Bonfanti L, 2015. Hepatitis E virus genotype 4 in a pig farm, Italy, 2013 . Epidemiol Infect 143:529-33.

Oliveira-Filho EF, König M, Thiel HJ, 2013. Genetic variability of HEV isolates: inconsistencies of current classification. Vet Microbiol 26:148-54.

Pavio N, Meng XJ, Renou C, 2010. Zoonotic hepatitis E: animal reservoir and emerging risks. Vet Res 41:46.

Purdy MA, Khudyakov YE, 2010. Evolutionary history and population dynamics of hepatitis E virus. PLoS ONE 5:e14376.

Rapicetta M, Monarca R, Kondili LA, Chionne P, Madonna E, Madeddu G, Soddu A, Candido A, Carbonara S, Mura MS, Starnini G, Babudieri S, 2013. Hepatitis E virus and hepatitis A virus exposures in an apparently healthy high-risk population in Italy. Infection 41:69-76.

Renou C, Afonso AM, Pavio N, 2014. Foodborne transmission of hepatitis $\mathrm{E}$ virus from raw pork liver sausage, France. Emerg Infect Dis. 20:1945-7.

Reuter G, Fodor D, Forgach P, Katai A, Szucs G, 2009. Characterization and zoonotic potential of endemic hepatitis $\mathrm{E}$ virus (HEV) strains in humans and animals in Hungary. J Clin Virol 44:277-81.

Romanò L, Paladini S, Tagliacarne C, Canuti M, Bianchi S, Zanetti AR, 2011. Hepatitis E in Italy: a long-term prospective study. $\mathbf{J}$ Hepatol 54:34-40.

Ruggeri FM, Di Bartolo I, Ostanello F, Trevisani M, 2013a. Hepatitis E virus. An emerging zoonotic and foodborne pathogen. Springer, Amsterdam, The Netherlands.

Ruggeri FM, Di Bartolo I, Ponterio E, Angeloni G, Trevisani M, Ostanello F, 2013b. Zoonotic transmission of hepatitis E virus in industrialized countries. New Microbiol 36:331-44.

Takahashi K., Kitajima N, Abe N, Mishiro S, 2004. Complete or near-complete nucleotide sequences of hepatitis $\mathrm{E}$ virus genome recovered from a wild boar, a deer, and four patients who ate the deer. Virology 330:501-5.

Tei S, Kitajima N, Takahashi K, Mishiro S, 2003. Zoonotic transmission of hepatitis $\mathrm{E}$ virus from deer to human beings. Lancet 362:371-3.

Van Cuyck H, Fan J, Robertson DL, Roques P, 2005. Evidence of recombination between divergent hepatitis E viruses. J Virol 930614.

Van der Poel WHM, Verschoor F, van der Heide R, Herrera MI, Vivo A, Kooreman M, de Roda Husman M, 2001. Hepatitis E virus sequences in swine related to sequences in humans, the Netherlands. Emerg Infect Dis 7:6.
Vasickova P, Psikal I, Widen F, Smitalova R, Bendova J, Pavlik I, 2009. Detection and genetic characterisation of hepatitis $\mathrm{E}$ virus in Czech pig production herds. Res Vet Sci 87:143-8.

Walachowski S, Dorenlor V, Lefevre J, Lunazzi A, Eono F, Merbah T, Eveno E, Pavio N and Rose N, 2014. Risk factors associated with the presence of hepatitis $\mathrm{E}$ virus in livers and seroprevalence in slaughter-age pigs: a retrospective study of 90 swine farms in France. Epidemiol Infect 142-9.

Yazaki H, Mizuo M, Takahashi M, Nishizaua T, Sasaki N, Gotanda Y, Okamoto H, 2003. Sporadic acute or fulminant hepatitis $\mathrm{E}$ in Hokkaido, Japan, may be food-borne, as suggested by the presence of hepatitis $\mathrm{E}$ virus in pig liver as food. $\mathrm{J}$ Gen Virol 84:2351-7.

Zanardi G, Antoniolli P, Gemma Brenzoni L, Tranquillo VM, Bonazza V, Bellini S, Avisani D, 2007. La malattia vescicolare del suino in Lombardia. Available from: http://www.izsler.it/izs_bs/ftp//doc/Archivio /2007/2007Aprile.pdf

Zanetti AR, Schlauder GG, Romanò L, Tanzi E, Fabris P, Dawson GJ, Mushahwar IK, 1999. Identification of a novel variant of hepatitis E virus in Italy. J Med Virol 57:356-60. 